\title{
JEMBATAN ASADISCO SEBAGAI UPAYA PENINGKATAN KOMPETENSI HOLISTIK PESERTA DIDIK PADA MATERI PENGHANTARAN IMPULS SARAF
}

\author{
Siti Khofifah \\ SMA Negeri 1 Sidayu, Gresik Jawa Timur \\ Email: biokhofifah@gmail.com
}

\begin{abstract}
Abstrak
Materi penghantaran impuls saraf merupakan materi yang sifatnya abstrak pada mapel biologi, sehingga kebanyakan peserta didik sangat sulit memahami konsep tersebut. Kesulitan itu terjadi karena di SMA Negeri 1 Sidayu belum ada media yang bisa digunakan untuk memvisualisasikan konsep materi secara konstektual sehingga hasil belajar peserta didik rendah karena selalu memakai metode ceramah. Selama ini juga penilaian hanya dilakukan pada kompetensi pengetahuan sedang sikap dan ketrampilan diabaikan. Untuk itu melalui media jembatan asadisco hasil kreativitas penulis akan maтрu menyelesaikan masalah yang ada, dengan tujuan penelitian untuk meningkatkan kompetensi holistik peserta didik pada materi penghantaran impuls saraf. Dengan Research and Development model 4-D Thiagarajani melalui tahapan pendefinisian, perancangan, pengembangan dan diseminasi. Implementasi dengan uji coba awal dan uji coba akhir. Ada validasi RPP, LAPD dan jembatan asadisco. Dengan instrumen berupa lembar penilaian diri, lembar observasi penilaian kompetensi holistik meliputi sikap, ketrampilan dan pengetahuan yang dianalisis secara deskriptif kualitatif sesuai taraf kompetensi yang ditentukan. Subyek peserta didik kelas XI MIPA-3 SMA Negeri 1 Sidayu berjumlah 32, putri 19 dan putra 13. Hasil uji coba awal kompetensi sikap 60\%, ketrampilan $70 \%$ dan pengetahuan $78,1 \%$ sedang uji coba akhir sikap $87 \%$, ketrampilan $88 \%$ dan pengetahuan 87.5\%. Kesimpulan bahwa jembatan asadisco dapat dijadikan sebagai upaya yang mampu meningkatkan kompetensi holistik peserta didik kelas XI MIPA-3 SMA Negeri 1 Sidayu pada materi penghantaran impuls saraf.
\end{abstract}

Kata Kunci: Jembatan Asadisco, Kompetensi Holistik.

\begin{abstract}
The purpose of this study was to improve students' holistic competence in the material for delivering nerve impulses through the development of the Asadisco Bridge. Asadisco Bridge is a neural flow bridge construction made from bottled drinking water waste, to describe sensory, connector and motor nerves in the event of nerve impulse delivery with discovery learning models. While holistic competence is the competency of students including attitudes, skills and knowledge. Thiagarajani Research and Development 4-D model research with the stages of defining, designing, developing and disseminating. Implementation with initial trials and final trials. There is validation of the RPP, LAPD and asadisco bridges. With instruments in the form of self-assessment sheets, holistic competency assessment observation sheets include attitudes, skills and knowledge analyzed descriptively qualitatively according to the specified competency level. The subjects of class XI MIPA3 students of SMA Negeri 1 Sidayu amounted to 32, 19 women and sons 13. The results of the initial
\end{abstract}


trials of attitude competency were increased. The conclusion is that the development of the Asadisco Bridge can improve the holistic competence of the students of Class XI MIPA-3 of SMA Negeri 1 Sidayu on the delivery of nerve impulses.

\section{Keywords: Asadisco Bridge, Holistic Competence}

\section{PENDAHULUAN}

Peraturan Menteri Pendidikan dan Kebudayaan nomor 22 tahun 2016 menjelaskan bahwa karakteristik proses pembelajaran harus disesuaikan dengan karakteristik kompetensi. Proses pembelajaran harus diarahkan pada pengembangan kompetensi sikap, pengetahuan, dan keterampilan secara holistik, dengan menggunakan pendekatan saintifik. Pendidik yang profesional harus terampil menggunakan model pembelajaran yang tepat, sehingga pembelajaran menjadi aktif, inovatif, kreatif, dan efektif, menekankan pada pemberian pengalaman belajar dan memperkuat pendekatan ilmiah (discovery/ inquiry learning) (Syarif, 2017:9).

Adanya fakta bahwa materi penghantaran impuls saraf merupakan salah satu materi yang sifatnya abstrak pada mata pelajaran biologi. Materi itu meliputi polarisasi, depolarisasi dan repolarisasi. Kebanyakan peserta didik sangat sulit memahami konsep tersebut. Kesulitan itu terjadi karena di SMA Negeri 1 Sidayu belum ada alat peraga yang bisa digunakan untuk memvisualisasikan konsep materi secara benar dan tepat, sehingga hasil belajar peserta didik rendah. Selama ini pembelajaran dilakukan pendidik dengan metode ceramah, media power point atau video yang ada di media sosial, sehingga hanya dapat melakukan penilaian kompetensi pengetahuan sedang sikap dan ketrampilan diabaikan. Padahal kurikulum 2013 di tahun 2017, pendidik harus memberi bekal peserta didik dengan ketrampilan abad 21 sehingga menjadi generasi emas di tahun 2045 yang mampu bersaing dalam kanca global. Ketrampilan abad 21 4C (Critical Thinking, Creative, Communication, dan Collaboration, karakter baik (religiusitas, nasionalisme, kemandirian, gotong royong, integritas) dan kemampuan literasi (numerasi, bahasa, sains, digital, finansial, budaya dan kewargaan) harus dimiliki peserta didik.

Menurut penelitian Selvia (2016:12), penggunaan kombinasi model pembelajaran picture and picture dan think talk write dapat meningkatkan hasil belajar dibandingkan model pembelajaran konvensional yaitu ceramah pada sistem saraf. Wahyuningsih (2011:109) juga menyatakan bahwa pengembangan media komik bergambar materi sistem saraf manusia dapat menumbuhkan sikap positif, meningkatnya minat membaca, aktivitas, dan hasil belajar peserta didik secara klasikal. Berdasarkan penelitian sebelumnya peneliti ingin melakukan pengembangan dengan metode konstruktivistik dan kerjasama dalam kelompok melalui jembatan asadisco dengan dasar bahwa penggunaan media tiga dimensi dapat meningkatkan aktivitas guru, aktivitas siswa dan hasil belajar siswa (Krisnawati, 2016: $1)$.

Untuk mewujudkan semua itu, dibutuhkan sikap kreatif dari seorang pendidik dalam proses pembelajaran sehingga akan dihasilkan peserta didik dengan otak cemerlang, tangan terampil dan berkarakter baik dengan cara meningkatkan kompetensi holistik peserta didik. Apalagi saat ini pelaksanaan kurikulum 2013 diusahakan harus mengintegrasikan STEAM (Science, Technology, Engineering, Art, Mathematics). Jembatan asadisco merupakan salah satu bentuk usaha kreatifitas 
pendidik menciptakan media yang akan mampu memvisualisasikan materi abstrak pada mapel biologi menjadi konstektual, sehingga mudah dipahami oleh peserta didik. Melalui jembatan asadisco maka kompetensi holistik peserta didik dapat diukur, karena Isbandiyah (2019:15) mengatakan bahwa mapel biologi bertujuan menumbuhkan sikap spiritual dan sosial yang diharapkan mampu membekali pengetahuan dan keterampilan kepada peserta didik, sehingga mereka mampu untuk menyelesaikan persoalan dalam kehidupan sehari-hari sebagai pribadi dan sebagai warga negara. Berdasarkan uraian diatas peneliti melakukan penelitian terkait jembatan asadisco dengan model discovery learning dengan rumusan masalah berupa "Bagaimana implementasi jembatan asadisco sebagai upaya meningkatkan kompetensi holistik peserta didik pada materi penghantaran impuls saraf ?"

\section{Kajian Pustaka}

\section{Jembatan Asadisco}

Jembatan asadisco merupakan media pembelajaran berupa konstruksi jembatan aliran saraf yang terbuat dari limbah botol kemasan air minum yang mendeskripsikan saraf sensoris, konektor dan motorik dalam peristiwa penghantaran impuls saraf, meliputi: polarisasi, depolarisasi dan repolarisasi. Dengan menggunakan model discovery learning, meliputi: stimulation, problem statement, data collection, data processing, verification dan generalization. Kustandi dan Sutjipto (2013: 8) berpendapat bahwa media pembelajaran adalah alat yang dapat membantu proses pembelajaran dan berfungsi memperjelas makna pesan yang disampaikan, sehingga dapat mencapai tujuan pembelajaran dengan lebih baik dan sempurna. pendidik dapat memanfaatkan media pembelajaran yang inovatif untuk melakukan perubahan dalam pembelajaran (Perovic, 2014).

Melalui jembatan asadisco materi akan divisualisasikan sehingga akan dihasilkan pemahaman yang utuh, bermakna dan akhirnya dapat meningkatkan kompetensi holistik peserta didik. Untuk pembuatan jembatan asadisco ada syarat ketentuan dalam pembuatan media, meliputi: tujuan pembelajaran, bahan pelajaran/materi, metode mengajar, ketersediaan alat dan bahan yang dibutuhkan, bisa didemonstrasikan, kondisi siswa, minat dan kemampuan pembelajar, situasi pengajaran yang sedang berlangsung (Sanaky, 2013: 6-7). Akhirnya dengan jembatan asadisco akan terjadi peningkatan kompetensi holistik peserta didik.

\section{Kompetensi Holistik Peserta Didik}

Kompetensi holistik adalah kompetensi yang utuh meliputi sikap, ketrampilan dan pengetahuan yang harus dikuasai oleh peserta didik. Dalam penelitian ini untuk kompetensi sikap terkait dengan tanggung jawab dalam membuat konstruksi dan saat diskusi, kompetensi ketrampilan terkait dengan kemampuan membuat kostruksi jembatan asadisco secara tepat sedang kompetensi pengetahuan terkait dengan hasil setelah post tes dengan ketuntasan minimal secara klasikal 75. Dengan jembatan asadisco kompetensi sikap bisa dibangun melalui kerjasama kelompok, sehingga diharapkan akan terwujud manusia yang memiliki pribadi beriman, berakhlak mulia, percaya diri, dan bertanggung jawab dalam berinteraksi secara efektif dengan lingkungan sosial, alam sekitar, serta dunia dan peradabannya. dengan sasaran penilaian sikap spiritual dan sosial meliputi: menerima, menanggapi, menghargai, menghayati, dan mengamalkan nilai (Kemendikbud. 2014:17) 
Melalui jembatan asadisco juga kompetensi ketrampilan dapat dibangun dengan cara pemberian tugas kelompok berupa merangkai konstruksi jembatan asadisco, sehingga akan terjadi peningkatan kompetensi ketrampilan peserta didik. Akhirnya diharapkan dapat mewujudkan manusia yang memiliki pribadi berkemampuan pikir dan tindak yang efektif dan kreatif dalam ranah abstrak dan konkret. Dengan sasaran penilaian keterampilan abstrak dan konkret. Keterampilan abstrak meliputi: mengamati, menanya, mengumpulkan informasi/mencoba, menalar - /mengasosiasi, dan mengkomunikasikan sedang keterampilan konkret meliputi: meniru, melakukan, menguraikan, merangkai, memodifikasi, dan mencipta.

Dengan jembatan asadisco akan tercipta pembelajaran yang berkualitas, bisa dilakukan secara konstektual, sehingga akan terjadi juga peningkatan kompetensi pengetahuan peserta didik. Akhirnya akan terwujud manusia yang memiliki pribadi yang menguasai ilmu pengetahuan, teknologi, seni, budaya dan berwawasan kemanusiaan, kebangsaan, kenegaraan, dan peradaban. Dengan sasaran penilaian meliputi: mengetahui, memahami, menerapkan, menganalisis, mengevaluasi dan mencipta dalam dimensi pengetahuan faktual, konseptual, prosedural, dan metakognitif (Permendikbud No. 104, 2014:4).

\section{Materi Penghantaran Impul Saraf}

Materi penghantaran impuls saraf dimulai ketika stimulus diterima oleh reseptor, lalu dihantarkan ke neuron sensoris, ke neuron konektor, lalu ke neuron motorik dan berakhir di efektor yang akan menanggapi rangsangan. Tiap neuron itu sendiri ada aliran impuls di mulai dari dendrit ke badan sel lalu ke akson dengan tiga peristiwa meliputi: polarisasi, depolarisasi dan repolarisasi.

Polarisasi terjadi jika tidak ada rangsangan dengan kondisi ion $\mathrm{Cl}-$ dan $\mathrm{Na}+$ lebih banyak di luar sel (ekstraseluler) sehingga membran luar bermuatan positif. Sedang Ion A- dan K+ lebih banyak di dalam sel (intraseluler) sehingga membran dalam sel saraf bermuatan negatif. Untuk depolarisasi terjadi jika ada stimulus yang diterima panca indra (reseptor), akibatnya terjadi potensial aksi (depolarisasi) dikarenakan ion $\mathrm{Na}+$ dan $\mathrm{Cl}$ - bergerak masuk ke dalam sel sehingga menyebabkan membran dalam bermuatan positif dan membran luar bermuatan negatif, setelah itu impuls dihantarkan neurotransmiter ke neuron sensoris lalu ke neuron konektor kemudian ke neuron motorik, lalu ke efektor berupa otot dan kelenjar. Sedang repolarisasi/refraktori terjadi bila impuls telah lewat, membran sel neuron akan kembali ke keadaan semula, di luar sel bermuatan positif dan di dalam bermuatan negatif. Ketika impuls mencapai ujung akson. Impuls tersebut harus melewati sinapsis menuju otot, kelenjar, atau saraf lainnya (Pujiyanto, 2008: 205-211) Berdasarkan uraian materi di atas, mekanisme penghantaran impuls saraf akan divisualisasikan melalui jembatan asadisco sehingga akan dihasilkan pemahaman yang utuh dan bermakna, akhirnya dapat meningkatkan kompetensi holistik peserta didik,

Solichin (2012:87) mengatakan bahwa kompetensi sikap terkait aspek emosional seperti perasaan, minat, sikap, kepatuhan terhadap moral dan sebagainya, mencakup penerimaan (receiving/attending), tanggapan (responding), tata nilai (valuing), pengorganisasian (organization), dan karakterisasi (characterization). Kompetensi ketrampilan terkait aspek yang melibatkan fungsi sistem syaraf dan otot (neuronmuscular system) dan berfungsi psikis. Sedang kompetensi pengetahuan berupa kemampuan berfikir meliputi faktual terkait mengingat, konseptual terkait memahami, prosedural 
terkait menerapkan, sedang metakognitif terkait menganalisis, mengevaluasi dan mencipta. Pembuatan konstruksi jembatan asadisco merupakan dimensi mencipta yang menuntut kemampuan memadukan unsur-unsur menjadi sesuatu bentuk baru yang utuh dan koheren, atau membuat sesuatu yang orisinil, meliputi proses menentukan pengetahuan penting dan tidak penting (strategic knowledge), pengetahuan yang sesuai konteks tertentu (operasi kognitif), dan pengetahuan diri (selfknowledge) (Sulaeman, 2017:39-41). Jika semua dimensi baik sikap, ketrampilan dan pengetahuan di miliki peserta didik maka akan terwujud generasi emas yang mampu bersaing dalam kanca global.

\section{METODE}

Penelitian ini merupakan jenis penelitian pengembangan model 4-D, yang terdiri 4 tahapan meliputi pendefinisian (define), perancangan (design), pengembangan (develop) dan diseminasi (disseminate) (Thiagarajan \& Semmel, 1974). Dengan menggunakan model discovery learning, meliputi: stimulation (pemberian stimulus), problem statement (menentukan pertanyaan mendasar), data collection (peserta didik melakukan kajian literatur), data processing (unjuk kerja mengkonstruksi jembatan asadisco), verification (melakukan kajian ulang terkait hasil konstruksi) dan generalization (presentasi kelompok). Tempat penelitian di SMAN 1 Sidayu Gresik, Jalan Pahlawan No. 06 Sidayu. Dengan alokasi waktu 2x45 menit ( 2 jam pelajaran) untuk uji coba awal dilaksanakan pada hari Kamis tanggal 27 April dan Selasa 2 Mei 2018. Subyek penelitian peserta didik kelas XI-3 berjumlah 32, putri jumlah 19 dan putra dengan jumlah 13 dengan tahapan sebagai berikut.

\section{Tahap pendefinisian (define)}

Pada tahap ini dilakukan analisis awal (front-end analysis), analisis peserta didik (learner analysis), analisis konsep (concept analysis), analisis tugas (task analysis) dan analisis tujuan pembelajaran (specifying instructional objectives).

- Analisis awal, ditemukan permasalahan yang terjadi selama ini kompetensi peserta didik rendah, motivasi rendah, metode ceramah dan tidak bisa dilakukan penilaian sikap dan ketrampilan.

- $\quad$ Analisis konsep (Concept Analysis), Materi aliran saraf ini bersifat abstrak, sehingga peserta didik sulit memahami. Dilakukan juga analisis KI dan KD terkait materi.

- Analisis tugas (Task Analysis), identifikasi tugas utama peserta didik pada proses pembelajaran, terkait unjuk kerja mengkonstruksi jembatan asadisco, dan mengidentifikasi apa yang dikaji peneliti.

- Analisis tujuan pembelajaran (Instructional Objectives), berupa menentukan IPK yang didasarkan atas analisis materi dan KD. 


\section{Tahap Perancangan (design)}

Tahap perancangan ini untuk merancang RPP, LAPD dan media jembatan asadisco. Dengan tahapan meliputi: penyusunan tes acuan (criterion-test construction), pemilihan media (media selection), pemilihan format (format selection) dan desain awal (initial design).

- $\quad$ Tahap tes acuan, berupa penyusunan tes acuan berupa lembar penilaian kompetensi holistik meliputi sikap, ketrampilan dan pengetahuan, tabel spesifikasi penilaian, lembar observasi sesuai deskriptor yang telah dibuat dan lembar penilaian diri serta lembar validasi.

- Pemilihan media, yang digunakan adalah jembatan asadisco dari limbah botol plastik kemasan air minum yang mendeskripsikan peristiwa polarisasi, depolarisasi pada penghantaran impul melewati neuron sensoris, neuron konektor dan neuron motorik.

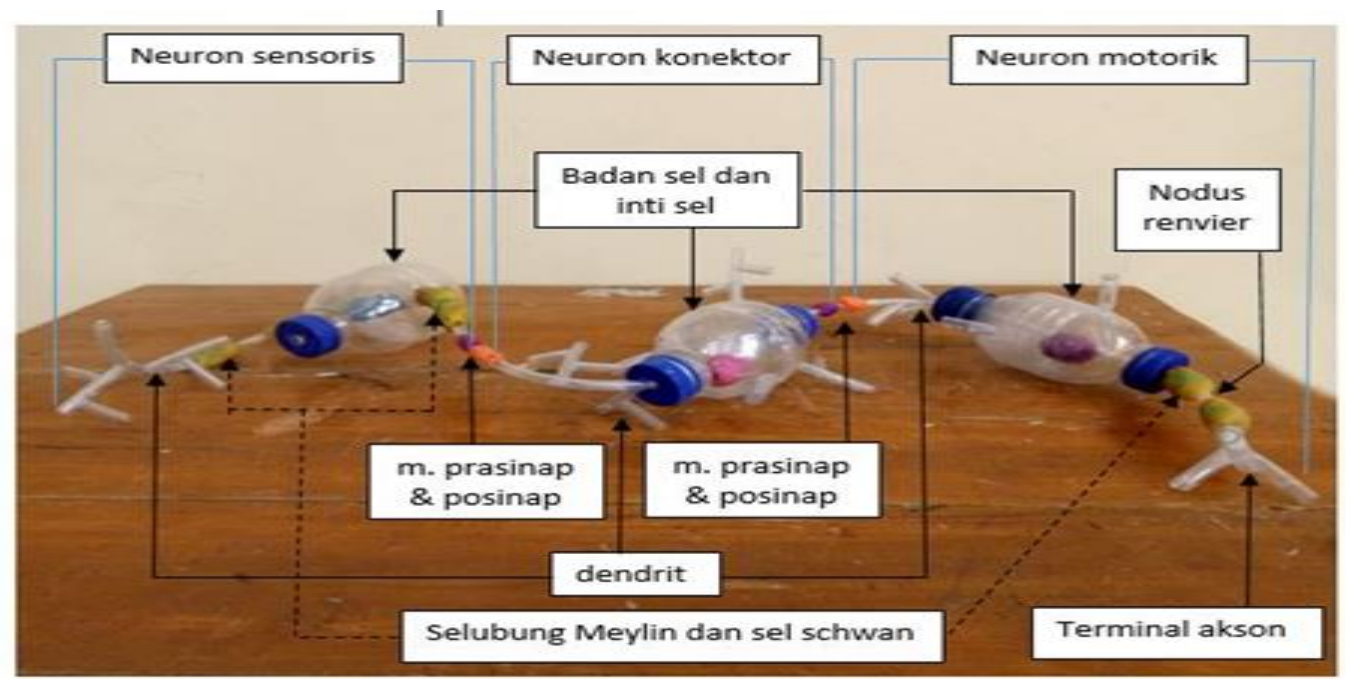

Setiap neuron baik sensoris, konektor dan motorik, aliran impulsnya dimulai dari dendrit ke badan sel kemudian ke akson seperti skema di bawah ini.

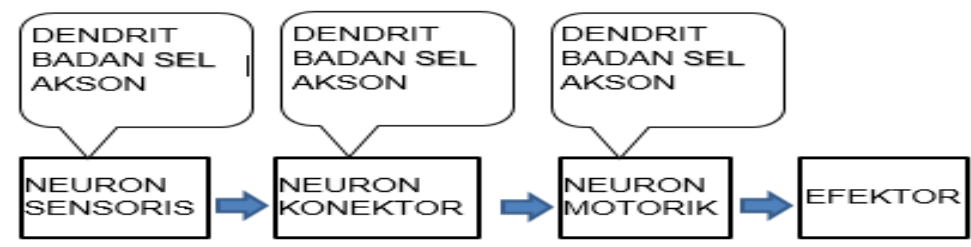

- Pemilihan format perangkat pembelajaran berupa silabus, RPP, LAPD sesuai dengan kurikulum 2013.

- Hasil dari perancangan sebagai draf I meliputi RPP, LAPD, dan jembatan asadisco yang akan diuji coba dan diketahui hasilnya. 


\section{Tahap Pengembangan (develop)}

Tahap pengembangan ini bertujuan untuk merevisi dan mengembangkan RPP, LAPD, jembatan asadisco (Draf II) berdasarkan masukan validator dan refleksi hasil uji coba peserta didik terkait kompetensi holistik, dengan dua langkah meliputi:

- $\quad$ Validasi Ahli (expert appraisal)

Validasi ahli ini berfungsi untuk memvalidasi RPP, LAPD, dan konstruksi jembatan asadisco draft I. Hasil validasi jika layak digunakan maka akan diuji coba awal, namun bila hasil validasi tidak layak, maka dilakukan revisi pada perangkat yang belum layak.

- $\quad$ Uji Coba Produk (development testing)

Pada tahap ini dilakukan uji coba produk. Bila hasil dari uji coba awal belum memenuhi KKM, maka produk berupa RPP, LAPD, dan jembatan asadisco harus direvisi. Hasil dari uji coba awal digunakan sebagai dasar dalam pengembangan dan revisi draf II.

\section{Tahap Diseminasi (diseminate)}

Tujuan dari tahap ini adalah menyebarluaskan RPP, media LAPD jembatan asadisco, dengan cara diseminasi di forum MGMP Biologi Kabupaten Gresik, dengan kerangka penelitian berupa:

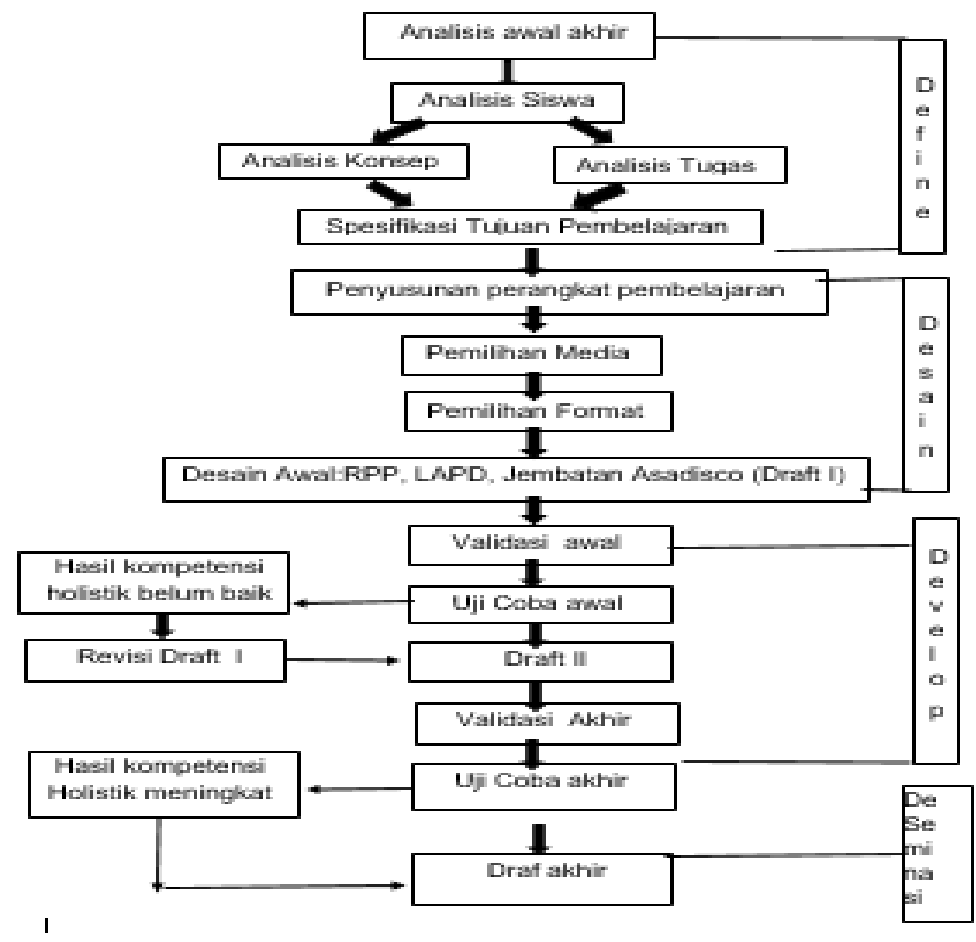

\section{Anaisis Data}

Data yang diperoleh dari uji coba awal dianalisis dengan deskriptif kualitatif. Untuk hasil validasi kelayakan RPP, LAPD, jembatan asadisco dari angket yang berisi pernyataan yang harus dipilih dan dinilai menggunakan skala kualitatif Likert dengan teknik checklist. Untuk pernyataan positif, SS=5, 
$\mathrm{S}=4, \mathrm{~N}=3, \mathrm{TS}=2, \mathrm{STS}=1$. Untuk pernyataan negatif, $\mathrm{STS}=5, \mathrm{TS}=4, \mathrm{~N}=3, \mathrm{~S}=2, \mathrm{SS}=1$. Dalam penelitian ini, pilihan netral dikategorikan dengan kategori cukup sehingga untuk pernyataan positif: $\mathrm{SS}=4, \mathrm{~S}=3$, $\mathrm{CS}=3 \mathrm{TS}=2, \mathrm{STS}=1$, pernyataan negatif: $\mathrm{STS}=4, \mathrm{TS}=3, \mathrm{CS}=3, \mathrm{~S}=2, \mathrm{SS}=1$. Data yang diperoleh dari setiap aspek dianalisis dengan mengunakan rumus:

Persentase hasil capaian $=\frac{\sum \text { skor yang dicapai }}{\sum \text { skor maksimum }} \times 100 \%$

Setelah itu, data dianalisis dengan memperhatikan skor tabel penentuan kelayakan yang ditentukan. Untuk kompetensi holistik dianalisis berdasarkan hasil observasi pada saat proses pembelajaran. Dalam hal ini observer yang terdiri dari guru biologi (peneliti) dan 2 rekan peneliti yang bertugas mengamati kompetensi sikap dan ketrampilan. Dengan standar ketuntasan minimal secara klasikal sebesar 75\% kategori cukup. Data yang diperoleh dianalisis dengan ketentuan taraf kompetensi sikap dan ketrampilan yang ditetapkan peneliti sesuai skor kompetensi masing-masing deskriptor sebagai berikut.

\begin{tabular}{llll}
\hline No & Skor & Presentase hasil Capaian & Ketentuan Kelayakan \\
\hline 1 & 1 & $0-20 \%$ & sangat tidak layak digunakan \\
\hline 2 & 2 & $21-40 \%$ & tidak layak digunakan \\
\hline 3 & 3 & $41-60 \%$ & cukup layak digunakan \\
\hline 4 & 4 & $61-80 \%$ & layak digunakan \\
\hline 5 & 5 & $81-00 \%$ & sangat layak digunakan \\
\hline
\end{tabular}

Lalu data dianalisis dengan taraf kompetensi sikap dan ketrampilan sesuai skor deskriptor di bawah ini.

\begin{tabular}{lllcc}
\hline No & $\begin{array}{c}\text { Persentase hasil sikap } \\
\text { /aktivitas }\end{array}$ & $\begin{array}{l}\text { Taraf Kompetensi } \\
\text { sikap/aktivitas }\end{array}$ & Nilai Huruf & $\begin{array}{c}\text { Nilai } \\
\text { Angka }\end{array}$ \\
\hline 1 & $0-34$ & Sangat Kurang & E & 1 \\
\hline 2 & $35-74$ & Kurang & D & 2 \\
\hline 3 & $75-79$ & Cukup & C & 3 \\
\hline 4 & $80-89$ & Baik & B & 4 \\
\hline 5 & $90-100$ & Sangat Baik & A & 5 \\
\hline
\end{tabular}

Untuk taraf kompetensi pengetahuan didasarkan pada hasil post tes sesuai dengan standar ketuntasan minimal secara klasikal dengan persentasi 75 kategori cukup, dengan ketentuan taraf kompetensi pengetahuan sebagai berikut. 


\begin{tabular}{lll}
\hline No & \multicolumn{1}{c}{ Persentasi Ketuntasan } & \multicolumn{1}{c}{ Taraf kompetensi pengetahuan } \\
\hline 1 & $0-34$ & Sangat Kurang \\
\hline 2 & $35-74$ & Kurang \\
\hline 3 & $75-79$ & Cukup \\
\hline 4 & $80-89$ & Baik \\
\hline 5 & $90-100$ & Sangat Baik \\
\hline
\end{tabular}

\section{HASIL DAN PEMBAHASAN}

\section{Hasil Uji Coba Awal}

Hasil validasi draft I oleh validator menunjukkan bahwa RPP sudah layak digunakan, LAPD dan Jembatan asadisco juga sudah sangat layak digunakan sehingga draft I sudah layak diuji coba pada kelas terbatas di SMA Negeri 1 Sidayu kelas XI MIPA-3. Dari hasil analisis, kompetensi holistik untuk sikap hasil uji coba awal 60\% kategori kurang dengan skor klasikal sebesar 18 dari skor klasikal maksimal 30. Untuk hasil ketrampilan sebesar 70\%, masih dalam kategori kurang dengan skor perolehan sebesar 28 dari skor maksimal sebesar 40. Sedang untuk kompetensi pengetahuan saat post tes sebesar 78,1\% kategori cukup dengan jumlah 25 peserta didik yang sudah memenuhi kriteria ketuntasan minimal dan 7 (21,8\%) peserta didik yang belum memenuhi kriteria ketuntasan minimal dengan jumlah total 32 peserta didik, sehingga dapat disimpulkan bahwa kompetensi sikap dan ketrampilan pada uji coba awal belum memenuhi kriteria ketuntasan minimal secara klasikal, yang telah ditentukan sebesar $75 \%$ di SMAN I Sidayu dengan predikat cukup, sedangkan kompetensi pengetahuan sudah memenuhi KKM tapi masih dalam kategori cukup.

Kenyataan di atas dikarenakan untuk kompetensi sosial berupa perilaku tanggung jawab dalam bekerja sama membuat konstruksi sebanyak 27 peserta didik (84\%) atau 4 kelompok yang menunjukkan kerjasama dengan kategori baik. Untuk kompetensi penilaian diri 24 (75\%) peserta didik dengan kategori cukup dalam pengakuan diri peringkat baik dan sangat baik. Sedang kompetensi yang belum memenuhi KKM ketika observasi saat diskusi. Sikap proaktif dalam diskusi kelas meliputi kompetensi mengajukan pertanyaan, hanya ada $6(19 \%)$ peserta didik, menjawab soal hanya ada 10 (31\%), mengajukan sanggahan pendapat dan ide, hanya ada 9 (28\%) peserta didik, sehingga semuanya kategori sangat kurang.

Hal ini dikarenakan proses diskusi kelas masih didominasi peserta didik dengan pengetahuan dan ketrampilan tinggi, diskusi belum berjalan dengan dinamis dan aktif. Akibatnya, tidak semua peserta didik memperoleh pengalaman belajar. Diskusi terkait mengajukan pertanyaan, sanggahan, pendapat, ide dan menjawab soal, hanya sedikit yang aktif karena tidak percaya diri, tingkat keberanian yang rendah, takut salah, sehingga cukup mewakilkan pada anggota kelompok yang ketrampilan dan pengetahuannya tinggi. Padahal pengalaman belajar penting dalam menentukan keberhasilan peserta didik untuk mencapai ketuntasan belajar. Kenyataan ini didasarkan pada pengakuan peserta didik dari angket.

Untuk kompetensi ketrampilan terkait kemampuan mengonstruksi jembatan asadisco meliputi struktur tiap neuron dan macam neuron: sensoris, konektor/ajustor dan motorik, hanya 4 kelompok 
dengan jumlah $22(69 \%)$ peserta didik, ketepatan merangkai konstruksi efektor $21(66 \%)$ peserta didik. Presentasi dan menulis laporan LAPD terkait rumusan masalah dan tujuan hanya ada 17 (53\%) peserta didik yang kompeten.

\section{Langkah Pengembangan}

Berdasarkan hasil uji coba awal maka peneliti melakukan pengembangan pada RPP, LAPD dan jembatan asadisco, meliputi:

- $\quad$ RPP pada tahap Generalization dari model discovery learning, pendidik membuat rancangan dengan menugaskan pada semua kelompok untuk mempresentasikan atau mendemonstrasikan hasil kerja kelompoknya berupa: konstruksi jembatan aliran saraf dan LAPD.

- $\quad$ LAPD dilakukan revisi pada komponen petunjuk kerja/prosedur yang dilengkapi gambar terkait pembuatan jembatan asadisco. Pada LAPD draft I banyak peserta didik yang kurang paham, sehingga hasil kompetensi ketrampilan terkait membuat konstruksi jembatan asadisco diperoleh hasil dengan kategori masih kurang. Untuk itu peneliti merevisi draft II dengan cara melengkapi prosedur kerja dengan gambar bentuk semua bagian yang terlibat peristiwa penghantaran impuls saraf. Hasil revisi berupa penyusunan LAPD draft II meliputi:

1. Mempersiapkan selang dengan panjang 1 meter dan 5 botol plastik bekas kemasan air minum, lem, plastisin dan kawat.

2. 1 botol plastik dipotong bagian ujung dan dasar seperti gambar (a) dan 4 botol plastik dipotong bagian ujungnya saja seperti gambar (b).

3. Selang plastik bagian ujung ditempeli dengan potongan selang, setelah itu menutupinya dengan plastisin bentuk bulat sel seperti gambar (c), sebagai visualisasi dari inti dan meletakkan potongan ujung botol di selang yang ditutupi plastisin seperti gambar (d).

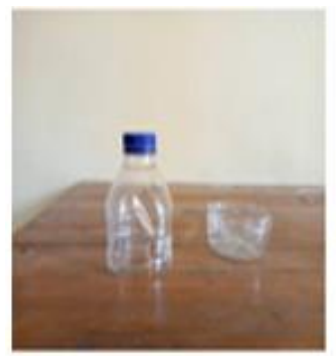

a

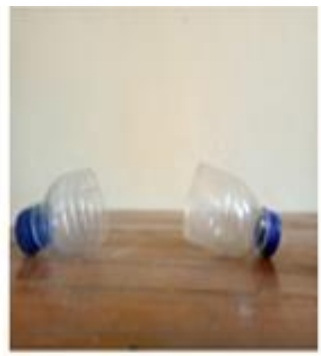

b

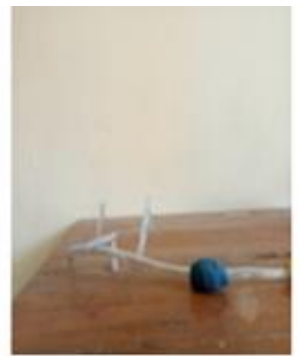

c

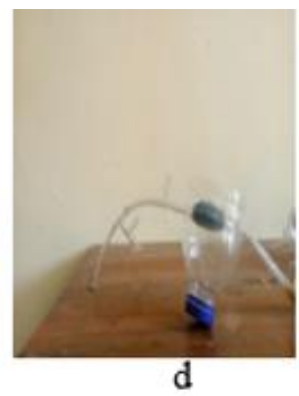

d

4. Menutup potongan ujung botol dengan potongan dasar botol seperti gambar (e), lalu selang yang keluar dari botol ditempeli dengan plastisin sebagai visualisasi dari selubung meylin, di atas lapisan plastisin ditempelkan plastisin dengan bentuk bulat kecil seperti gambar (f), sebagai visualisasi dari sel schwan.

5. Menempelkan plastisin pada selang dengan lebar $1 \mathrm{~cm}$ sebanyak dua kali sebagai membran prasinap dan postsinap, dan antar keduanya diberi jarak, kemudian menempelkan potongan selang kecil di atas selang panjang seperti gambar $(\mathrm{g})$.

6. Memasukkan potongan ujung botol pada selang yang sudah ditempeli plastisin kemudian menutupnya dengan potongan ujung botol juga, seperti gambar (h). 


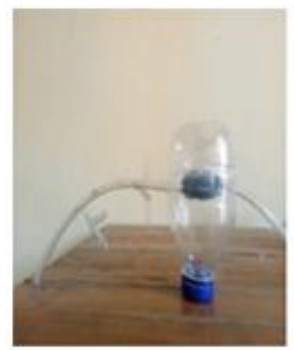

e

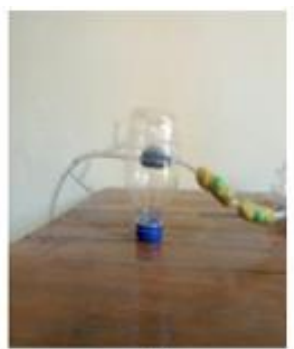

f

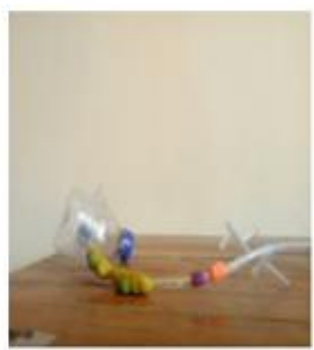

g

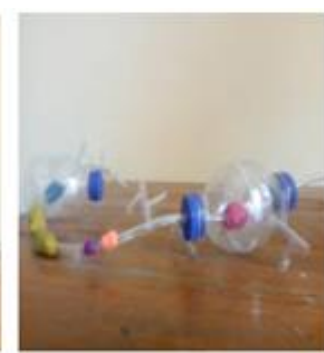

$\mathrm{h}$

7. Selang yang keluar dari botol kedua ditempeli dengan plastisin seperti cara kerja 5 dengan hasil seperti gambar (i).

8. Melakukan langkah kerja nomor 6 kemudian ujung selang yang masuk ke botol pertama dan yang keluar dari botol ketiga ditempeli plastisin, diatas lapisan plastisin ditempelkan plastisin dengan bentuk bulat kecil. Kemudian ujung selang ditempeli dengan potongan selang sebagai terminal akson seperti gambar (j).

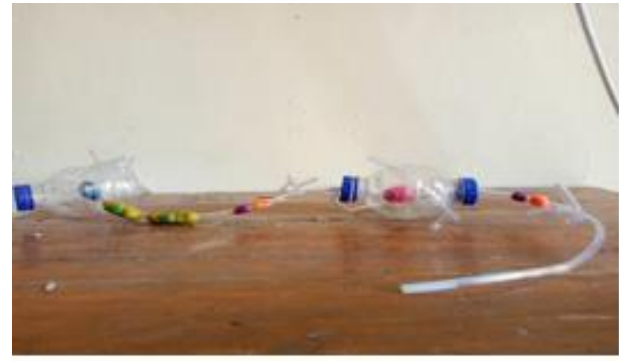

I

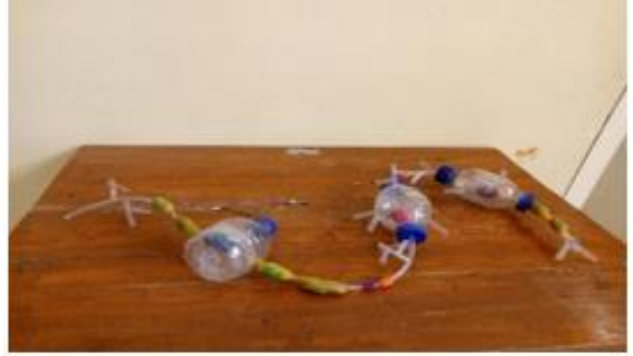

j

9. Membuat kincir plastik dari botol plastik seperti gambar di bawah ini, lalu membuatkan peyangga dari gabus styrofoam sebagai visualisasi dari efektor.

10. Meletakkan konstruksi jembatan asadisco diatas penyangga kaki tiga, kemudian meletakkan kincir plastik sebagai visualisasi efektor di dekat ujung terminal akso, untuk mendemonstrasikan polarisasi dan depolarisasi seperti gambar.

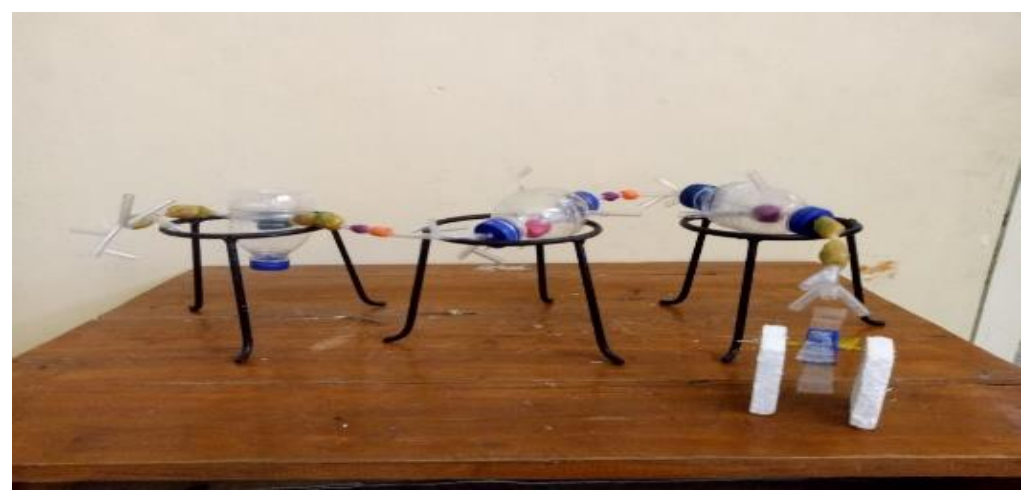


- Jembatan asadisco yang dibuat oleh pendidik sudah layak digunakan tapi yang dibuat oleh peserta didik belum lengkap dalam mendeskripsikan komponen-komponen yang terlibat dalam penghantaran impuls. Untuk itu LAPD dilengkapi dengan gambar pada prosedur.

- $\quad$ Peneliti memberikan angket penilaian diri pada peserta didik

\section{Hasil Uji Coba Akhir}

Hasil analisis pada uji coba akhir untuk kompetensi sosial sebesar $87 \%$, ketrampilan $88 \%$ sedang kompetensi pengetahuan $87.5 \%$. Kompetensi sikap diperoleh nilai 26 dari skor maksimum 30 kategori baik dari perilaku tanggung jawab dalam bekerja sama mendemonstrasikan jembatan asadisco ada 32 (100\%) peserta didik dari 6 kelompok siap sedia, sehingga kategori sangat baik. Sedang kompetensi sosial terkait kompetensi mengajukan pertanyaan 18 (56\%), menjawab soal 20 (63\%) meningkat bila dibandingkan uji coba awal. Untuk kompetensi mengajukan sanggahan pendapat dan ide 30 (94\%) peserta didik dengan taraf keberhasilan tindakan sangat baik. Begitu pula untuk hasil dari penilaian diri $32(100 \%)$ peserta didik dengan nilai baik dan sangat baik.

Untuk kompetensi ketrampilan hasil uji coba akhir (draft II) sebesar 88\%, kategori baik dengan skor sebesar 35 dari skor maksimal sebesar 40. Hal ini menunjukkan adanya peningkatan kompetensi ketrampilan terkait hasil observasi dalam mendemonstrasikan peristiwa polarisasi, depolarisasi, sudah ada $27(84 \%)$ peserta didik sehingga kategori baik, menulis laporan LAPD terkait rumusan masalah $100 \%$ kategori sangat baik, presentasi LAPD 22 (69\%), merumuskan tujuan, menjawab pertanyaan $32(100 \%)$ peserta didik dengan taraf kompetensi ketrampilan sangat baik. Sedang kompetensi pengetahuan dari post tes ke 2 mengalami peningkatan setelah dilakukan perbaikan pada draft I pada LAPD dan RPP. Hasil uji coba awal 78,1\% kategori cukup menjadi 87,5\% kategori baik, dengan jumlah $28(82,4 \%)$ memenuhi kriteria ketuntasan minimal kategori sangat baik, dengan rincian 8 (25\%) peserta didik sangat baik, $11(34,4 \%)$ peserta didik kategori baik, 9 (28,1\%) peserta didik kategori cukup, sedang kategori kurang $4(12,5 \%)$ peserta didik. Untuk peserta didik yang belum memenuhi standar KKM dengan jumlah $6(17,6 \%)$ dari 32 peserta didik.

\section{Implementasi Pengembangan Jembatan Asadisco}

Permendikbud nomor 22 tahun 2016 menjelaskan bahwa karakteristik proses pembelajaran harus disesuaikan dengan karakteristik kompetensi. Proses pembelajaran harus diarahkan pada pengembangan kompetensi sikap, pengetahuan, dan keterampilan secara holistik, dengan menggunakan pendekatan saintifik. Pendidik yang profesional, tidak hanya menguasai materi pembelajaran, tetapi juga terampil menggunakan model pembelajaran yang tepat, sehingga pembelajaran menjadi aktif, inovatif, kreatif, dan efektif. Pembelajaran Biologi di SMA, harus menekankan pada pemberian pengalaman belajar secara langsung bagi peserta didik, sehingga untuk memperkuat pendekatan ilmiah perlu diterapkan pembelajaran berbasis penyingkapan penelitian (discovery/ inquiry learning) (Syarif, 2017: 9).

Berdasarkan uraian di atas, maka sudah bisa dipastikan bahwa pengembangan jembatan asadisco dapat meningkatkan kompetensi holistik peserta didik pada materi penghantaran impuls saraf. Hal ini dibuktikan dari hasil analisis uji coba awal dan uji coba akhir. Hasil uji coba awal kompetensi sikap $60 \%$, ketrampilan $70 \%$ dan pengetahuan $78,1 \%$ sedang uji coba akhir sikap $87 \%$, ketrampilan $88 \%$ 
dan pengetahuan $87,5 \%$. Terbukti sudah dengan pembelajaran yang menuntut untuk mengkonstruksi jembatan asadisco akan mampu memberikan pengalaman belajar kontekstual dan melatih kompetensi ketrampilan peserta didik. Pendidik juga dapat melakukan penilaian kompetensi ketrampilan dan sikap, yang selama ini hanya menilai kompetensi pengetahuan dengan capaian sangat rendah, karena kebanyakan memakai sistem hafalan dalam penguasaan materi. Apalagi aliran sistem saraf merupakan materi abstrak. Tidak ada kerangka pemahaman yang utuh karena pembelajaran belum bisa dilakukan secara kontekstual sehingga mengakibatkan motivasi belajar peserta didik rendah yang berujung hasil belajar peserta didik juga rendah.

Untuk kompetensi ketrampilan, uji coba awal hasilnya kategori kurang (70\%), dikarenakan selama ini kompetensi ketrampilan belum terlatih dengan baik, sehingga tuntutan mengonstruksi jembatan asadisco masih kurang tepat. Kurang kerja sama secara baik, tidak semua anggota kelompok bertanggung jawab dalam tugas secara tepat waktu, kurang teliti akhirnya hasilnya kurang tepat. Revisi LAPD draft I akhirnya dapat meningkatkan kompetensi peserta didik dalam mengonstruksi jembatan asadisco dengan tepat dan lengkap yang memuat semua komponen yang terlibat dalam penghantaran impuls saraf. Jika konstruksi tepat maka kompetensi ketrampilan meningkat dan akan memberi konstruksi pemahaman yang utuh bagi peserta didik sehingga akan mampu meningkatkan kompetensi pengetahuan, sehingga penilaian kompetensi ketrampilan harus dilakukan. Bonwell dan Eison menyatakan bahwa penilaian kompetensi ketrampilan harus dilakukan, karena akan dapat menciptakan pembelajaran yang aktif. Pembelajaran bukan hanya menyampaikan informasi, melainkan menekankan pada pengembangan keterampilan berpikir analistis dan kritis. Peserta didik tidak mendengarkan secara pasif, tetapi mengerjakan sesuatu berkaitan materi pelajaran, mengeksplorasi nilai, sikap serta dituntut kritis menganalisa dan mengevaluasi dengan umpan balik yang lebih cepat pada proses pembelajaran (Machmudah, 2008:64).

Dengan membuat jembatan asadisco yang dikerjakan berkelompok, akan menuntut adanya sikap tanggung jawab dan bekerja sama/gotong royong dari setiap anggota untuk menyelesaikan tugas. Interaksi dan komunikasi dalam pembelajaran yang menciptakan suatu kondisi yang memungkinkan terjadinya tindakan belajar sehingga peserta didik menguasai kompetensi yang telah ditentukan (Arifin, 2013: 10). Penguatan pendidikan karakter juga dapat terlaksana, akhirnya kompetensi sikap peserta didik juga meningkat. Untuk itu penilaian kompetensi sikap harus dilakukan, karena kompetensi sikap sangat penting dalam membangun karakter peserta didik sebagai generasi penerus bangsa dan terwujudnya manusia yang memiliki pribadi beriman, berakhlak mulia, percaya diri, dan bertanggung jawab dalam berinteraksi secara efektif dengan lingkungan sosial, alam sekitar, serta dunia dan peradaban (Kemendikbud, 2014:17).

Untuk kompetensi pengetahuan hasil uji coba awal menunjukkan bahwa tidak semua peserta didik menguasai materi yang didiskusikan, akibatnya tingkat pemahamannya masih kurang akibat tidak mengikuti pengalaman belajar secara aktif pada saat diskusi. Akhirnya dilakukan revisi RPP draf I tahap generalization, yang menugaskan tidak hanya pada kelompok yang mau saja tapi semua kelompok harus mempresentasikan hasil kerja kelompoknya. Semua anggota kelompok pada saat diskusi harus bergantian menjelaskan, menjawab dan berpendapat, supaya semua menguasai materi yang didiskusikan dan yang dipresentasikan. Kelas tidak lagi didominasi peserta didik yang ketrampilan dan pengetahuannya tinggi. Keaktifan dalam diskusi juga akan dinilai secara materi supaya kompetensi pengetahuan meningkat. Peserta didik yang menguasai kompetensi dapat terlihat 
melalui hasil belajar yang dicapainya. Hasil belajar menunjukkan kualitas peserta didik (Fathoni dan Riyana, 2011: 147). Berkaitan dengan uraian di atas, revisi yang dilakukan pada draft I baik pada RPP, LAPD dan jembatan asadisco sebagai langkah untuk memberikan pengaruh positif bagi peningkatan kompetensi holistik peserta didik SMAN 1 Sidayu kelas XI MIPA-3 pada materi penghantaran impuls saraf. Akhirnya terbukti bahwa terjadi peningkatan kompetensi holistik peserta didik baik sikap, ketrampilan maupun pengetahuan.

Berdasarkan kenyataan di atas, maka dapat ditegaskan bahwa ketika peserta didik dibebani tugas secara individu sebagai anggota kelompok dalam melakukan presentasi, maka sebagai individu akan berusaha bertanggungjawab pada kelompoknya. Rasa ingin tahu akan meningkat karena tidak ingin dicemooh dan ingin diakui keberadaannya dalam kelompok. Akhirnya pemahaman juga akan meningkat dan pada akhirnya kepercayaan diri meningkat sehingga kompetensi dalam menjawab dan mengemukakan pendapat, gagasan dan ide akan meningkat. Hal ini membuktikan bahwa pengalaman belajar konstektual akan memberi manfaat penting bagi kesuksesan proses dan tujuan pembelajaran. Dengan cara membuat konkret berbagai konsep yang abstrak, menghadirkan media dan menampilkannya di ruang kelas (Indriana, 2011: 48-49).

Pembelajaran dengan alat peraga berupa jembatan asadisco juga dapat meningkatkan keingintahuan dan menyenangkan peserta didik dari hasil angket yang diberikan peserta didik. Peserta didik yang jenuh sulit untuk menerima materi sehingga dapat dikatakan bahwa pembelajaran yang aktif dapat berdampak positif terhadap prestasi peserta didik (Hamouda \& Tarlochan, 2015). Karena sesungguhnya hasil belajar tidak hanya dipengaruhi oleh kecerdasan tetapi juga faktor lain seperti motivasi, bakat, minat, media dan metode pembelajaran yang digunakan. LAPD yang diberikan juga mampu meningkatkan kerja sama, sharing dan tanggung jawab individu dalam kelompok. Skema gambar pada LAPD sangat membantu peserta didik dalam merevisi konstruksi jembatan asadisco secara lengkap. Akhirnya kompetensi pengetahuan peserta didik meningkat. Moch Syarif (2017:9) mengatakan bahwa pembelajaran Biologi di SMA harus memberikan pengalaman belajar secara langsung. Akhirnya proses pembelajaran yang berkualitas akan tercipta dan hasil pembelajaran juga akan meningkat baik sikap, ketrampilan dan pengetahuan. Begitu juga pada penelitian ini terbukti sudah bahwa jembatan asadisco sebagai salah satu upaya yang dapat meningkatkan kompetensi holistik peserta didik pada materi penghantaran impuls saraf. Karena pada dasarnya pelajaran biologi bertujuan untuk menumbuhkan sikap spiritual dan sosial, yang diharapkan mampu membekali pengetahuan dan keterampilan kepada peserta didik untuk mampu menyelesaikan persoalan dalam kehidupan sehari-hari (Isbandiyah, 2019:15).

\section{SIMPULAN DAN SARAN}

Berdasarkan hasil penelitian yang telah dilakukan maka dapat dibuat kesimpulan bahwa jembatan asadisco dapat dijadikan sebagai upaya yang mampu meningkatkan kompetensi holistik peserta didik kelas XI MIPA-3 SMA Negeri 1 Sidayu pada materi penghantaran impuls saraf. Hal ini dibuktikan dari hasil analisis data pada uji coba awal dan uji coba akhir. Hasil uji coba awal kompetensi sikap $60 \%$, ketrampilan $70 \%$ dan pengetahuan $78,1 \%$ sedang uji coba akhir sikap $87 \%$, ketrampilan $88 \%$ dan pengetahuan $87,5 \%$. Hal ini bisa terjadi setelah dilakukan pengembangan dari aspek RPP pada tahap generasilsasi pada model discovery Learning dan dari aspek LAPD dilakukan revisi pada 
komponen petunjuk kerja/prosedur yang dilengkapi gambar terkait pembuatan jembatan asadisco. Terbukti sudah dengan pembelajaran yang menuntut untuk mengonstruksi jembatan asadisco akan mampu memberikan pengalaman belajar kontekstual yang mampu meningkatkan kompetensi peserta didik meliputi sikap, ketrampilan dan pengetahuan.

Dengan mempertimbangkan hasil penelitian dari implementasi jembatan asadisco ini maka diharapkan pendidik mapel biologi dapat memanfaatkannya sebagai salah satu upaya proses pembelajaran di kelas untuk meningkatkan kompetensi holistik peserta didik pada materi penghantaran impuls saraf.

\section{DAFTAR RUJUKAN}

Arifin, Z. (2013). Evaluasi Pembelajaran. Bandung: Remaja Rosdakarya

Fathoni, T \& Riyana, C. (2011). Komponen- komponen Pembelajaran. Bandung: Alfabeta

Hamouda, A. M. S., \& Tarlochan, F. (2015). Engaging Engineering Students in Active Learning and Critical Thinking through Class Debates. Procedia - Social and Behavioral Sciences

Hujair A.H. Sanaky. (2013). Media Pembelajaran Interaktif-Inovatif. Yogyakarta: Kaukaba Dipantara

Indriana, D. (2011). Ragam Alat Bantu Media Pengajaran. Yogyakarta: Diva Press.

Isbandiyah, S. (2019). Modul Penyusunan Soal Ketrampilan Berfikir Tingkat Tinggi. Jakarta: Kemendikbud.

Kemendikbud. (2014). Materi Pelatihan Guru Implementasi Kurikulum (2013) Tahun Ajaran (2014/2015) Mapel Biologi. Jakarta: BPSDMPK-PMP Kemendikbud.

Krisnawati, A. (2016). Penggunaan Media Tiga Dimensi Untuk Meningkatkan Hasil Belajar Di Sekolah Dasar. JPGSD Volume 01 Nomor 02 Tahun 2013, 0-216.

Kustandi, C. \& Sutjipto, B. (2013). Media Pembelajaran: Manual dan Digital. Bogor: Ghalia Indonesia.

Machmudah, U. (2008). Active Learning dalam Pembelajaran Bahasa Arab. UIN-Malang Pres

Permendikbud RI Nomor 104. (2014). Penilaian Hasil Belajar oleh Pendidik pada Pendidikan Dasar dan Pendidikan Menengah. Jakarta: Mendikbud

Permendikbud RI Nomor 22 . (2016). Standar Proses Pendidikan Dasar Dan Menengah. Jakarta: Kemendikbud

Perovic, S. (2014). Collaborative Research and Urban Educational Discourse in Contemporary Higher Education. Procedia - Social and Behavioral Sciences, 116: 4559-4563.

Pujiyanto, S. (2008). Menjelajah Dunia Biologi 2. Solo: PT Tiga Serangkai Pustaka Mandiri

Selvia, D. (2016). Pengaruh Kombinasi Model Pap Dan TTW Terhadap Hasil Belajar Siswa SMA Submateri Sistem Saraf Manusia Pendidikan Biologi, Universitas Tanjungpura. Jurnal Pendidikan dan Pembelajaran Khatulistiwa Vol 6, No 6 Tahun 2017

Solichin, M.M. (2012). Psikologi Belajar: Aplikasi Teori-Teori Belajar Dalam Proses Pembelajaran. Yogyakarta: Suka Press. 
Sulaeman, A. A. (2017). Modul F PKB Biologi SMA: Penilaian Proses dan Hasil Belajar. Jakarta: P4TK IPA Dirjen GTK Kemendikbud.

Syarif, M. (2017). Modul D PKB Biologi SMA/SMK: Model Pembelajaran Ipa Dan Implementasinya. Jakarta: P4TK IPA Dirjen GTK Kemendiknas.

Thiagarajan, S. \& Semmel, D. (1974). Instructional Development for Training Teachers of Expectional Children. Minnesota: Leadership Training Institute of Special Education, University of Minnesota.

Wahyuningsih, A. N. (2011). Pengembangan Media Komik Bergambar Materi Sistem Saraf Untuk Pembelajaran Yang Menggunakan Strategi Pq4r . Jurnal PP Volume 1, No. 2, Desember 2011. ISSN 2089-3639 